\title{
UPAYA MENINGKATAN PRESTASI BELAJAR TOLAK PELURU DENGAN LATIHAN PUSH UP SISWA KELAS 7 C SEMESTER 2 SMP NEGERI 1 KESUGIHAN TAHUN PELAJARAN 2010 / 2011
}

\author{
HARDANA \\ SMP Negeri 1 Kesugihan Cilacap \\ Email: hardanaspd@gmail.com
}

\begin{abstract}
ABSTRAK
Atletik adalah olahraga terukur yang mempunyai objektifitas tinggi, dan banyak sekali medaliyang diperebutkan. Sayang banyak atlet atau pelatih juga pembina olahraga kurang minat untuk berprestasi dalam cabang ini, maka penulis sudah sejak lama mulai tertarik ingin mengembangkan olahraga yang ada di Amerika disebut "Track and Field". Penelitian ini menggunakan metode diskriptif dengan study korelasionar. Populasi penelitian adalah siswa dan siswi SMP Negeri 1 Kesugihan Cilacap tahun 2010/ 2011, sambil mengajar materi penjaskes penulis menyisipkan (Push Up) sebagai latihan wajib yang masuk dalam pemanasan bagi putra $15 \mathrm{kali}$ dan putri 10 kali. Pengamatan bersama selama 3 bulan atau 12 kali, tujuannya meningkatkan ketrampilan prestasi tolak peluru pada siswa. Penulisan ini diharapkan berrmanfaat bagi siswa dan guru agar ketrampilan melakukan tolak peluru meningkat serta dalam merancang, melaksanakan, mengevaluasi proses belajar mengajar hasilnya optimal. Penelitian dilaksanakan dalam dua siklus tiap siklus terdiri dari, perencanaan, pelaksanaan, tindakan observasi dan refleksi. Setelah dilaksanakan penambahan model latihan PUSH UP ketrampilan siswa meningkat, ini menunjukkan bahwa PUSH UP dapat meningkatkan kompetensi ketrampilan Tolak Peluru siswa kelas 7 C semester 2 SMP Negeri 1 Kesugihan Tahun Pelajaran 2010/ 2011.
\end{abstract}

Kata Kunci : Prestasi Belajar, Olahraga, Push Up

\section{PENDAHULUAN}

Globalisasi adalah masa suatu perkembangan yang sangat dahsyat hampir disemua ini mengalami perubahan. Perubahan itu meliputi sosial, politik, perekonomian, budaya, bahkan perubahan dibidang pendidikan. Dalam menghadapi globalisasi ini diperlukan semua dukungan dari semua bidang ilmu pengetahuan yang saling kait mengait, sehingga menjadi suatu kesatuan yang akhirnya menjadikan hasil pembangunan akan sempurna. Untuk mencapai semua tujuan itu diperlukan badan yang sehat dengan jalan berolahraga, olahragapun berkembang yang luar biasa pesatnya, seorang guru Penjaskes perlu mengikuti inovasi pendidikan ini. Olahraga yang menekankan kekuatan otot lengan (push up) sudah dikenal semua siswa bahkan sudah dikenal dimasyarakat, bahkan gerakan ini menjadi latihan wajib yang harus dilakukan para karate-do peserta kegiatan ekstra kurikuler SMP Negeri 1 Kesugihan Cilacap, agar mempunyai pukulan keras dan kuat. Olahraga push up sudah menjadi kebiasaan gerakan di fitnes (kebugaran), senam aerobik kelompok jantung sehat, kelompok sepakbola, beladiri, dan kelompok olahraga lainnya.

Olahrahga dalam pengertian umum adalah merupakan segala bentuk kegiatan yang mempergunakan kapasitas fisik manusia. Dalam perkembangannya, pengertian olahraga menjadi lebih sempit karena gerak-gerak tubuh tertentu kemudian memiliki konsep, artinya tidak semua kegiatan yang mempergunakan gerak tubuh disebut olahraga. Dengan munculnya kesadaran akan pentingnya olahraga bagi kesehatan jasmani, maka olahraga dikembangkan baik secara individu, oleh masyarakat maupun penguasa. Pengembangannya melalui berbagai jalur, baik jalur organisasi, masyarakat, maupun pendidikan. Melalui jalur pendidikan merupakan pengembangan olahraga yang strategis, karena dapat mencapai berbagai tujuan seperti menyehatkan generasi, mengembangkan olahraga itu sendiri dan mempersiapkan kader olahragawan. 
Tolak peluru merupakan bagian dari nomor lempar, nomor ini mempunyai karakteristik tersendiri yaitu peluru tidak dilemparkan tetapi ditolakkan atau didorong dari bahu dengan satu tangan. Berat peluru yang digunakan dalam perlombaan nasional dan olimpiade untuk putra $7,27 \mathrm{~kg}$ dan putri $4 \mathrm{~kg}$.

Cabang olahraga atletik pada nomor tolak peluru kurang digemari di masyarakat, baik untuk dilihat maupun untuk dilakukan. Pada umumnya tolak peluru dilakukan untuk tujuan meraih prestasi. Jarang sekali orang yang melakukan tolak peluru dengan rekreasi. Seperti dijelaskan oleh Sajoto (1995: 1-2) sebagai berikut:

Pertama adalah yang melakukan kegiatan olahraga untuk rekreasi, kedua mereka yang melakukan olahraga untuk tujuan mencapai tingkat kesegaran jasmani, dan keempat adalah mereka yang melakukan kegiatan olahraga untuk mencapai prestasi tertentu. Tolak peluru merupakan nomor lempar yang memiliki kekhususan dibanding nomor lempar lainnya, proses gerakanya membutuhkan banyak faktor yang menambah kesempurnaan geraknya, gerak lurus beraturan dan gerak lurus lurus berubah beraturan merupakan kombinasi yang terjadi dalam penolakan peluru. Hal itu membuktikan betapa komplek dan rumitnya dalam melakukan tolak peluru. Untuk itu seorang atlet tolak peluru memerlukan kondisi fisik yang prima, agar hasil tolakan dapat maksimal.

Pada dasarnya melakukan gerakan tolak peluru terdiri dari gerakan berkesinambungan dari persiapan awalan, melakukan awalan, saat menolakkan peluru, saat peluru lepas, dan pemeliharaan keseimbangan. Dengan pengklasifikasian tersebut akan mempermudah cara penguasaan, latihan dan pengembangannya. Meskipun demikian, efisiensi gerak dan efektivitas gerak tubuh dalam nomor tolak peluru sangat dibutuhkan, dengan gerak mengerahkan sedikit tenaga, akan menghasilkan lemparan yang sejauh-jauhnya. Untuk itu diperlukan penguasaan teknik-teknik gerak dan langkah tolak peluru serta kondisi fisik, bentuk dan postur tubuh serta anggota badan yang baik.

Penelitian ilmiah yang mempertemukan antara pengalaman dalam praktek dan perkembangan alami/ wajar, membuat dunia atletik berkembang menuju ke suatu taraf yang tidak diimpikan sebelumnya. Namun proses ini tidak harus menghalalkan segala cara yang tujuannya mencapai sesuatu rekor dengan mengorbankan pelakunya. Pendidikan jasmani di sekolah merupakan aktifitas fisik dalam bentuk aktifitas gerak siswa, saat melakukan tugastugas dalam proses pembelajaran.Dengan kata lain pendidikan jamani di sekolah adalah kegiatan belajar gerak. Dimana yang tadinya tidak bisa menjadi bisa atau terjadi perubahan tingkah laku setelah ada proses pembelajaran. Belajar gerak berlangsung secra bertahap atau tidak langsung jadi, belajar gerak dimulai dari belum bisa menjadi terampil dan dari terampil menjadi mampu melakukan gerakan secara otomatis, prestasi yang diperoleh dari siswa hanya dari proses belajar gerak, tidak seperti halnya prestasi yang diperoleh dari latihan olahraga prestasi, di mana dalam olahraga prestasi telah diterapkan prinsip-prinsip latihan.

Tujuan dari tolak peluru adalah melempar atau menolak semaksimal mungkin. Untuk bisa melempar secara maksimal, ada tiga aspek biomekanika. Aspek tersebut dijelaskan oleh Harald Muler (2000: 129) bahwa: “ Tingginya melepaskan alat ditentukan dengan tingginya badan si atlet meskipun ini dipengaruhi oleh posisi atlet saat melepaskannya. Kecepatan alat itu dilepaskan dan sudut lepas adalah keduanya hasil dari gerakan atlet menjelang dan selama lepasnya alat.

SMP Negeri 1 Kesugihan Cilacap adalah salah satu sekolah negeri dari 57 SMP di kabupaten Cilacap, dengan jumlah kelas 16. Dengan jumlah siswa 657 dan 28 guru serta 12 karyawan yang bermisi dan visi "beriman, berkualitas, terampil, dan berbudaya". Letaknya kurang lebih $25 \mathrm{~km}$ dari kota Cilacap dan berlokasi di lereng gunung, dan dari utara ke selatan mengalir sungai serayu, pada waktu terjadi gelombang Tsunami, daerah kami menjadi tempat pengungsian sehingga Pesanggrahan tempat sekolah kami semakin dikenal,. Untuk mencapai prestasi tinggi harus kerja keras, disiplin tinggi, dan kematangan juara. Untuk pencapaian olahraga yang maksimal perlu adanya dukungan dari semua pihak, faktor penentu pencapaian olahraga tersebut menurut Mohamat sarjoto (1995: 2) adalah: 
1. Aspek biologis

2. Aspek psikologis

3. Aspek lingkungan

4. Aspek penunjang

Pada prinsipnya untuk mencapai prestasi optimal dalam tiap cabang olahraga harus dengan latihan secara modern, dari masing - masing cabang memerlukan kekhususan di dalam kepelatiahan. Menurut Suharno H. P (1992: 2) mengatakan "faktor penentu pencapaian prestasi maksimal:

1. Faktor indogen dari atlet, fisik, proposial tubuh, kemampuan fisik, penguasaan teknik, masalah individu, kejiwaan dan kepribadian kematangan juara.

2. Faktor endogen dari luar, pelatih, tempat, alat, organisasi, lingkungan, partisipasi pemerintah, metoda dan sistem latihan.

Kedua faktor ini sebagai penentu pencapaian prestasi maksimal, sebagai dasar pembina dan pelatih demi keberhasilan suatu pendidikan olahraga disekolah sesuai yang diharapkan. Suharsini Arikunto (2008: 2) menjelaskan bahwa arah dan tujuan penelitian tundakan kelas dilakukan demi kepentingan peserta didik dalam memperoleh hasil yang memuaskan . Untuk mrningkatkan hasil belajar siswa dan tindakan yang dilakukan berdasarkan atas upaya meningkatkan hasil yang lebih baik dari pada sebelumnya dan ide yang dicobakan harus cemerlang.

Dari penemuan dilapangan dan pantauan kepada siswa hasil belajar rendah dikarenakan:

1. Guru kurang memperhatikan proses belajar mengajar dilapangan

2. Motivasi belajar siswa kurang dalam menyerap pelajaran di kelas maupun di lapangan

3. Tidak ada kepedulian orang tua dalam perkembangan pendidikannya kususnya dilingkungan keluarga

4. Lingkungan masyarakat sekitar siswa yang kurang mendukung sehingga prestasi menurun

5. Kurangnya sarna dan prasarana baik dirumah, sekolah maupun lingkungan yang mendukung prestasi siswa di sekolah

Berdasarkan analis bersama dengn teman sejawat kemungkinan faktor penyebab kurangnya motivasi belajr siswa adalah: 1) Penjelasan guru kurang abstrak b) Model pembelajaran guru tidak tepat c) Guru tidak mampu mengembangkan dialok yang efektif d ) Guru tidak mengadakan multi media dalam kegiatan belajar mengajar .

Dalam Penelitian Tindakan Kelas ini diharapkan bermanfaat bagi siswa dan guru untuk :

1. Untuk meningkatkan manfaat gerakan yang menekankan kekuatan otot lengan (push up)

2. Untuk meningkatkan teknik latihan gerakan tolak peluru bagi siswa.

3. Mengetahui manfaat latihan kekuatan otot (push up) terhadap prestasi tolak peluru Dengan latihan push Up diharapkan akan memacu munculnya kekuatan, yang menurut Suharno HP :

1. Kekuatan maksimal adalah kemampuan otot dalam kontraksi maksimal serta dapat melawan/ menahan beban yang maksimal sangat dibutuhkan bagi lifter.

2. Kekuatan daya ledak adalah kemampuan kekuatan sebuah otot atau segerombolan otot untuk mengatasi tahanan beban dengan kecepatan tinggi dalam satu gerakan utuh.

3. Power endurance (kekuatan dan tahan lama) adalah kemampuan tahan lamanya kekuatan otot melawan tahanan beban yang tinggi intensitasnya. Misalnya mendayung, balap sepeda, berenang, dll.

Push Up adalah gerakan kedua tangan dengan mengangkat bahu dengan mengangkat naik dan menurunkan badan ,gerakan untuk melatih kekuatan otot lengan (push up) Gerakan push up ada 2 macam: 
1. Floor push up untuk putra.

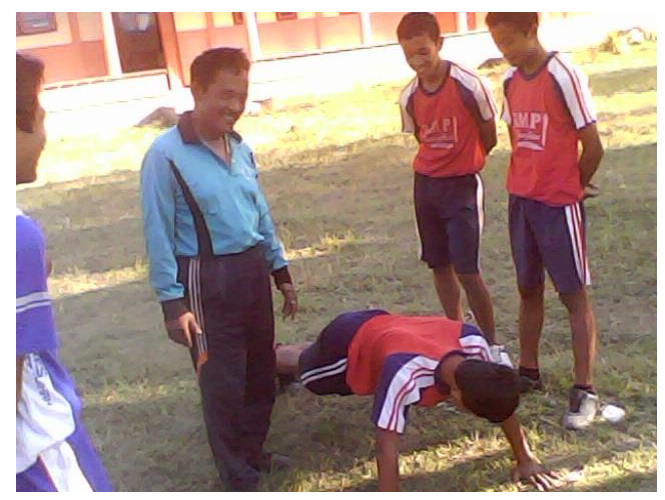

2. Modified push up untuk putri:

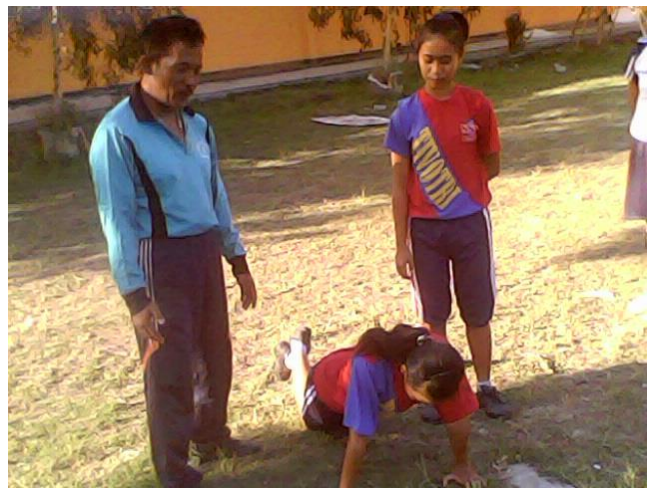

1. Floor push up untuk putra.

Pelaksanaannya:

1) Dua orang saling membantu, satu melakukan push up satu melakukan menghitung dalam jumlah tertent hitungan lurus selebar bahu.

2) Testi mengambil posisi tengkurap kaki lurus kebelakang ttangan lurus kebelakang tangan lurus terbuka selebar bahu.

3) Turunkan badan sampai dada menyentuh matras atau lantai kemudian dorong kembali keatas ke posisi semula dalam satu hitungan.

4) Lakukan sebanyak mungkin tanpa istirahat.

2. Modified push up untuk putri:

Pelaksanaannya:

1) Testi mengambil posisi tengkurap lutut ditekuk lengan lurus terbuka selebar bahu badandisangga oleh lengan.

2) Turunkan badan sampai dada menyentuh matras atau kemudian dorong kembali keatas ke posisi semula dalam satu hitungan .

3) Lakukan sebanyak mungkin tanpa diselingi istirahat.

4) Pada saat mendorong keatas lengan tidak lurus badan tidak lurus melengkung atau menyudut.

\section{METODE PENELITIAN}

Penelitian yang dipakai dengan Penelitian Tindakan Kelas bertujuan untuk mengadakan perbaikan atau peningkatan mutu praktik pembelajaran di kelas melalui PTK guru senantiasa memperbaiki praktik pembelajaran di kelas berdasarkan pengalaman-pengalaman langsung dan nyata di pandu dengan perluasan wawasan ilmu pengetahuan dan penguasan teoritik praktis pembelajaran. (Sarwiji Suwandi (2008: 20) Pada awal penelitian Sebagian besar siswa mengalami hambatan dalam melakukan ketrampilan tolak peluru. Hambatan timbul karena kurangnya motivasi dan belum adanya model pembelajaran yang dapat mereka jadikan contoh melakukan ketrampilan melakukan tolak peluru dengan baik. Penelitian dilaksanakan di lingkungan / halaman olah raga yaitu bulan Maret, April dan Mei 2011. Sumber Data pada penelitian ini merunpaka nilai hasiil observasi/ pengamatan pada siswa. Jenis Data yang dikumpulkan dalam penelitian ini diolah dengan menggunakan teknik kualitatif dan kuantitatif yang terdiri atas : 1 ) Hasil pembelajaran 2) Situasi pembelajaran 3 ) Keterkaitan antara rencana dan pelaksanaan tindakan kelas 4) Jurrnal, berupa catatan mengenai tahap pembelajarandan hasil yng dicapai

Pengumpulan data pada penelitian ini menggunakan teknik observasi/ pengamatan. Observasi dilakukan untuk menggali data, data yang diambil adalah hasil observasi tentang kejenuhan siswa dalam belajar tolak peluru.

Proses pengumpulan data meliputi: Pertama diadakan observasi/ pengamatan. Kegiatan tersebut dilaksanakan dalam pelaksanaan pre-tes dengan model pembelajaran konfensional, 
untuk mengetahui tingkat kejenuhan siswa dalam belajar tolak peluru sebagai patokan analisis selanjutnya. Kedua melakukan observasi/ pengamatan pada siklus I, dan ketiga melakukan observasi/ pengamatan pada siklus II yaitu pembelajaran tolak peluru dengan penambahan modifikasi Push Up

Langkah-langkah yang ditempuh dalam pengumpulan data ada tiga tahap. Tahap pertama observasi terhadap siswa pembelajaran tolak peluru dengan menggunakan peluru standar/ pembelajaran konfensional. Tahap pertama ini merupakan data pre-test. Tahap kedua melakukan observasi pembelajaran tolak peluru pada siklus I pembelajaran tolak peluru dengan menggunakan penambahan modifikasi Push Up Tahap ketiga melakukan kegiatan yang sam dengan kegiatan pada siklus I. Hasil dari observasi pre-test, siklus I dan siklus II, menunjukan peran serta siswa dalam belajar tolak peluru yang dilaksanakan selama penelitian, yang selanjutnya sebagai tolak ukur tingkat kejenuhan siswa pada pembelajaran tolak peluru.

Alat pengumpul data berupa lembaran observasi/ pengamatan untuk mengamati peranserta. Instrumennya berupa lembaran observasi.

Pelaksanaan observasi dilakukan dengan proses dan langkah-langkah sebagai berikut:

1. Persiapan, berupa kegiatan penyusunan rencana, pembuatan instrumen dan persiapan tempat dan alat yang akan digunakan.

2. Pelaksanaan observasi kepada seluruh siswa kelas VII SMP Negeri 1 Kesugihan.

3. Hasil observasi siswa, sesuai dengan pedoman yang dibuat.

4. Mengolah skor menjadi nilai akhir.

Setelah adanya penambahan model PUSH UP dan melakukan observasi/ pengamatan sebagai berikut:

1. Siswa senang dalam belajar tolak peluru

2. Siswa kreatif dalam belajar tolak peluru

3. Siswa semangat dalam belajar tolak peluru

4. Siswa suka mempraktekkan gerakan tolak peluru

5. Siswa bersikap baik dengan guru

6. Siswa mau bertanya tentang kesulitannya kepada guru

7. Siswa mau membantu guru dalam menyiapkan alat peluru

Data pada penelitian ini dilakukan dengan cara analisis deskriptif kwantitatif dengan presentase. Proses analisis dapat di gambarkan sebagai berikut:

Pretest :

Pretest dimaksudkan untuk patokan awal dalam menganalisis data. Pada pretest guru mengadakan observasi/ pengamatan pada siswa dalam belajar tolak peluru secara konfensional. Pembelajaran ini berkaitan dengan pengalaman guru selama proses pembelajaran tolak peluru sebelum penelitian tindakan kelas (PTK), baik kelebihan maupun kekurangannya. Pengambilan data kondisi awal ini akan digunakan untuk pathokan analisis berikutnya.

Siklus I :

Siklus I mengadakan pengamatan aktivitas belajar tolak peluru siswa dengan menggunakan penambahan Push Up . Pengamatan pada siklus I bertujuan untuk mengetahuiperubahan aktifitas siswa. Diharapkan pada siklus I keterlibatan siswa dalam belajar tolak peluru akan meningkat. Artinya tingkat kejenuhan siswa akan menurun.

Siklus II :

Siklus II mengadakan pengamatan sebagaimana pada siklus I tentang aktivitas/ keterlibatan belajar tolak peluru siswa dengan menggunakan prnambahan modivikasi latihan Push Uph pengamatan pada siklus II bertujuan sama dengan pada siklus I. Diharapkan pada siklus II keterlibatan siswa dalam belajar tolak peluru akan meningkatkan lagi di bandingkan pada siklus I .

\section{Kriteria keberhasilan :}


Kriteria keberhasilan berupa, harapan untuk setiap siklus. Harapan pada siklus I tingkat kejenuhan siswa tinggal $30 \%$ atau dapat diartikan bahwa partisipasi siswa mencapai $70 \%$ sedangkan siklus II akan mengacu pada refleksi dari siklus I.

Penelitian ini merupakan penelitian tindakan kelas (PTK) sehingga desain penelitiannya mengacu pada desain PTK. Menurut Kurt Lewin dalam Sarwiji Suwandi (2008: 33-34), menggambarkan penelitian tindakan sebagai serangkaian langkah yang membentuk spiral. Setiap langkah memiliki empat tahap, yaitu perencanaan (planning), tindakan (acting), pengamatan (observasing), dan refleksi (reflecting).

Langkah-langkah itu dapat dilihat pada gambar dibawah ini:

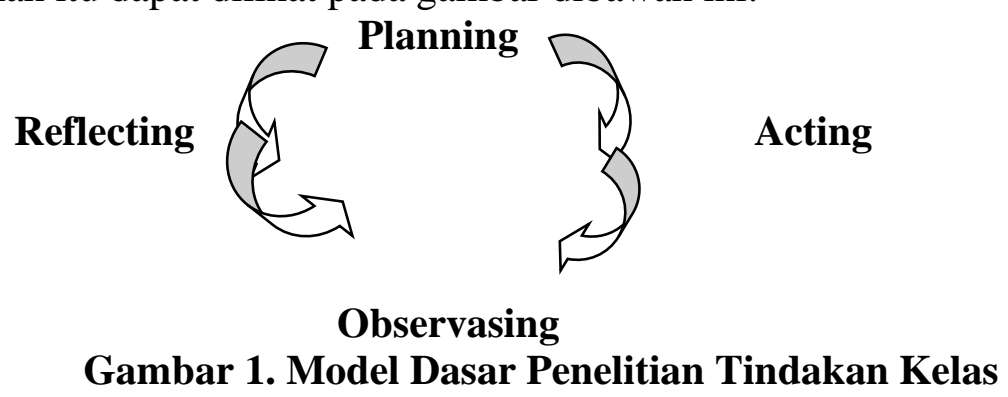

Keempat komponen dalam prosedur penelitian untuk setiap siklus, dapat diuraikan sebagai berikut:

Siklus 1 :

Tindakan pada siklus 1 menggunakan 4 langkah, yaitu: 1) perencanaan, 2) tindakan, 3) observasi, 4) refleksi. Pada tahap tindakan, pembelajarannya menggunakan langkah-langkah sebagai berikut: 1) tahap Orientasi, 2) tahap Inti Pembelajaran, dan 3) Penutup.

1. Perencanaan

Tahap perencanaan dugunakan untuk mempersiapkan berbagai sarana dan pelaksanaan tindakan. Hal-hal yang dipersiapkan antara lain: rencana pembelajaran, sarana kegiatan, kegiatan inti, dan kegiatan akhir. Alat kegiatan pada siklus I adalah berupa lapangan tolak peluru, bola plastik, bendera. Siklus I merupakan awal penelitian cara mengatasi kejenuhan siswa dalam belajar tolak peluru dengan modifikasi peluru. Pelaksaan evaluasi dengan pengamatan/ observasi.

2. Tindakan

1) Tahap orientasi

Guru melakukan kegiatan awal ini, yaitu mengabsen siswa, memusatkan perhatian, melakukan pemanasan, memotivasi siswa dan membagi menjadi beberapa kelompok.

2) Tahap Inti Pembelajaran

Inti pembelajaran pada siklus I diawali dengan penjelasan materi oleh guru atau peneliti. Masing-masing kelompok belajar tolak peluru. Guru dan siswa sama-sama aktif dalam pembelajaran ini sehingga suasana tetap meriah dan menyenangkan. Akhir dari kegiatan siklus 1 adalah tes tolak peluru untuk memotivasi siswa.

3) Tahap Penutup

Pada tahap ini guru menjelaskan tentang manfaat belajar tolak peluru. Dan menginformasikan pertemuan selanjutnya.

4) Observasi

Pelaksanaan observasi dilakukan oleh pelaksana tindakan dengan berkolaborasi dengan satu orang kolaborator. Siklus I berkolaborasi dengan guru kelas VII yang pada saat pelaksanaan tindakan siklus I ini siswa kelas VII sedang mengikuti pelajaran pendidikan jasmani. Digunakan kolaborator dengantujuan untuk lebih menjaga obyektivitas, terutama pada pegamatan aktivitas sisw dalam pembelajaran.

5) Refleksi

Pada tahap ini diawali dengan siklus antara pelaksana tindakan dengan kolaborator untuk membahas tentang hasil observasi siklus I. Kegiatan ini untuk menemukan 
kelebihan dan kekurangan pada pelaksanaan siklus-1. Siklus-1 ini diharapkan tingkat

\begin{tabular}{|l|l|l|}
\hline No & Nilai Siswa & Nilai \\
\hline
\end{tabular}

kejenuhan siswa dapat berkurang.

\section{Siklus II}

Tindakan pada siklus II sama dengan siklus I yaitu menggunakan 4 langkah, meliputi: 1) perencanaan, 2) tindakan, 3) observasi, 4) refleksi. Pada tahap tindakan, pembelajarannya menggunakan langkah-langkah sebagai berikut: 1) Tahap orientasi, 2) Tahap Inti Pembelajaran, 3) Penutup.

1) Tahap Orientasi

Guru melakukan kegiatan awal ini, yaitu mengabsen siswa, memusatkan perhatian, melakukan pemanasan, menyampaikan tujuan pembelajaran, memotivasi siswa dan membagi menjadi beberapa kelompok.

2) Tahap Inti Pembelajaran

Inti pembelajaran pada siklus I diawali dengan penjelasan materi oleh guru atau peneliti. Masing-masing kelompok belajar tolak peluru. Guru dan siswa sama-sama aktif dalam pembelajaran ini sehingga suasana tetap meriah dan menyenangkan. Akhir dari kegiatan siklus II adalah tes tolak peluru untuk memotivasi siswa.

3) Tahap Penutup

Pada tahap ini guru menjelaskan tentang manfaat belajar tolak peluru. Dan menginformasikan pertemuan selanjutnya.

1. Observasi

Pelaksanaan observasi dilakukan oleh pelaksana tindakan dengan guru kelas VII yang pada saat pelaksanaan tindakan siklus II ini siswa kelas VII sedang mengikuti pelajaran pendidikan jasmani. Digunakan kolaborator dengan tujuan untuk lebih menjaga obyektivitas, terutama pada pengamatan aktivitas siswa dalam pembelajaran.

2. Refleksi

Pada tahap ini diawali dengan diskusi antara pelaksana tindakan dengan kolaborator untuk membahas tentang hasil observasi siklus II. Kegiatan ini untuk menemukan kelebihan dan kekurangan pada pelaksanaan siklus-II. Siklus II ini diharapkan tingkat kejenuhan sudah tidak ada. Indikator Kinerja Keberhasilan PTK adalah jika mencapai $85 \%$ siswa menguasai kompetensi dasar diukur dari keberhasilan siswa melakukan latihan Push Up .Kriteria mengukur tingkat keberhasilan perbaikan pembelahjaran Tolak peluru ini adalah:

1) Proses KBM dikatakan berhasil bila daya keberhasilan / daya serap siswa mencapai 85\% dan siswa tuntas belajar dengan KKM 73

2) Prosesperbaikan pembelajaran tolak peluru dinyatakan berhasil siswa teribat aktif 85 $\%$ dalam mengikuti KBM. Ketuntasan melakukan Tolak peluru meliputi: tahap awal , luncuran, tahap akhir dan tolakan,

\section{HASIL DAN PEMBAHASAN}

\section{Hasil Siklus 1 :}

Pembelajaran siklus pertama ini dilaksanakan sesuai dengan rencana . penerapan model PUSH UP bertujuan untuk meningkatkan prestasi Tolak Peluru. Model penambahan latihan PUSH UP dilakukan agar sesuai atau melebihi KKM yang ditentukan, yaitu 73,00. Penilaian kompetensi lompat jauh meliputi: : tahap awal, luncuran, tahap akhir dan tolakan. Rentang nilai yang diperoleh pada siklus pertama ini adalah terlihat pada tabel berikut : 


\begin{tabular}{|l|l|l|}
\hline 1 & $96-100$ & \multicolumn{2}{|l|}{} \\
\hline 2 & $91-95$ & \multicolumn{2}{|l|}{} \\
\hline 3 & $86-90$ & 2 \\
\hline 4 & $81-85$ & 9 \\
\hline 5 & $76-80$ & 14 \\
\hline 6 & $71-75$ & 1 \\
\hline 7 & $66-70$ & 4 \\
\hline 8 & $61-65$ & 4 \\
\hline 9 & $56-60$ & 2 \\
\hline 10 & $\ldots . .-55$ & \multicolumn{2}{l|}{} \\
\hline Jumlah & $\mathbf{2 9 0 7}$ \\
\hline Rata-rata & $\mathbf{7 6 , 5}$ \\
\hline Siswa Tuntas & $\mathbf{2 3}$ & $\mathbf{6 3 , 8 8} \%$ \\
\hline Siswa Belum Tuntas & $\mathbf{1 3}$ & $\mathbf{3 6 , 1 1} \%$ \\
\hline
\end{tabular}

\section{Tabel 1. Rentang Nilai pada Siklus I}

Pada siklus pertama ini terlihat pada penguasaan dan kurang memahami: : tahap awal, luncuran, , tahap akhir dan tolakan sebagian besar siswa masih terlihat ragu dan hasil yang kurang sempurna serta banyak yang kurang percaya diri, ini bisa diketahui dari hasil KKM yang diperoleh 13 anak masih memperoleh dibawah rata-rata. Dilihat dari hasil siklus pertama ini sedikit siswa yang bisa membantu guru untuk menjadi contoh bagi teman-temannya melakukan hasil tolak peluru yang diharapkan, Hambatan itulah yang menjadikan pembelajaran ini belum bisa tuntas sehingga ketercapaian latihan tolak peluru ini harus lebih dioptimalkan, walaupaun ada beberapa siswa yang bisa mencapai nilai 90 dari empat aspek penilaian tolak peluru ini.

\section{Hasil Siklus 2 :}

Dari hasil hambatan dan kelemahan yang ditemukan siklus 1 dikaji dan diperbaiki serta dievaluasi, pada siklus kedua ini dimulai dengan perencanaan dengan mempertimbangkan hasil semua pencapaian siklus 1 .Setelah dilakukan rentang waktu latihan yang telah direncanakan dengan penambahan PUSH UP . Pada pembelajaran kedua ini siswa tertarik mengikuti pembelajaran tolak peluru . melakukan dengan senang lebih -lebih setelah diperkenalkan model PUSH UP . Para siswa mengerti hambatan dan kesulitannya dia semakin responsif dan antusias apa saja yang membuat kesulitan dalam melakukan tolak Peluru ini. Dalam menanggapi guru dan teman siswa semakin spontan terbawa alur ketika guru memperagakan contoh latihan Tolak Peluru setelah memakai PUSH UP sebagai tambahan model melatih siswa dalam lompat jauh diperoleh rata -rata pembelajaran sebagai berikut:

Tabel 2. Nilai Rata-Rata Pembelajaran

\begin{tabular}{|l|l|l|}
\hline No & Nama Siswa & Nilai \\
\hline 1 & $96-100$ & \\
\hline 2 & $91-95$ & 4 \\
\hline 3 & $86-90$ & 4 \\
\hline 4 & $81-85$ & 15 \\
\hline 5 & $76-80$ & 9 \\
\hline 6 & $71-75$ & 2 \\
\hline 7 & $66-70$ & 1 \\
\hline 8 & $61-65$ & \\
\hline 9 & $56-60$ & 1 \\
\hline
\end{tabular}




\begin{tabular}{|l|l|l|l|}
\hline 10 & $\ldots . .-55$ & \multicolumn{2}{|l|}{} \\
\hline Jumlah & $\mathbf{3 1 5 7 7}$ \\
\hline Rata-rata & $\mathbf{8 3 , 0 8}$ \\
\hline Siswa Tuntas & $\mathbf{3 2}$ & $\mathbf{8 9 , 4 7 \%}$ \\
\hline Siswa Belum Tuntas & $\mathbf{4}$ & $\mathbf{1 0 , 5 3 \%}$ \\
\hline
\end{tabular}

Dengan adanya penambahan latihan model Push UP ini ternyata ada kemajuan yang signifikan pada siklus 2 ini dari 36 siswa mengalami peningkatan mencapai kompetensi yang membanggakan .jumlah siswa yang mencapai angka memuaskan pada siklus ke 2 ini lebih banyak dari pada siklus pertama. Latihan yang diberikan pada siklus kedua ini model latihannya semakin ditingkatkatkan dari semua aspek pembelajaran lompat jauh meliputi: : tahap awal, luncuran, tahap akhir dan Tolakan.dan ditambah latihan model Push Up. Teknik latihan ini membawa siswa hasil yang signifikan , peningkatan dari hasil latihan dari setiap siklus bisa dilihat pada tabel pembanding meningkat pada latihan silklus kedua seperti pada tabel ini:

Tabel 3. Pembanding Siklus

\begin{tabular}{|c|c|c|c|}
\hline No & Nama Siswa & $\begin{array}{l}\text { NILAI } \\
\text { SIKLUS } 1\end{array}$ & $\begin{array}{l}\text { NILAI } \\
\text { SIKLUS } 2\end{array}$ \\
\hline 1 & $96-100$ & & \\
\hline 2 & $91-95$ & & 4 \\
\hline 3 & $86-90$ & 2 & 4 \\
\hline 4 & $81-85$ & 9 & 15 \\
\hline 5 & $76-80$ & 14 & 9 \\
\hline 6 & $71-75$ & 1 & 2 \\
\hline 7 & $66-70$ & 4 & 1 \\
\hline 8 & $61-65$ & 4 & \\
\hline 9 & $56-60$ & 2 & 1 \\
\hline 10 & $\ldots .55$ & & \\
\hline \multicolumn{2}{|c|}{ Jumlah } & 2907 & 31577 \\
\hline \multicolumn{2}{|c|}{ Rata-rata } & 76,5 & 83,08 \\
\hline \multicolumn{2}{|c|}{ Siswa Tuntas } & $23 \quad 63,88 \%$ & $32 \quad 89,47 \%$ \\
\hline \multicolumn{2}{|c|}{ Siswa Belum Tuntas } & $13 \quad 336,11 \%$ & $10,53 \%$ \\
\hline
\end{tabular}

\section{Pembahasan}

Pembelajaran Tolak Peluru pada mulanya dengan sederhana tanpa menggunakan alat bantu latihan, ternyata dalam menguasai kompetensi tersebut keberhasilan pembelajaran siswa ini hanya 63,88 \% siswa yang memperoleh nilai tuntas KKM ,sedangkan 36,11\% siswa belum mencapaiketuntasan yang diharapkan. Penyebab utama adalah kurang variasinya model pembelajaran pada siklus 1 , faktor keberanian untuk melakukan tolak peluru pada siswa masih ragu sehingga menyebabkan kegagalan sebagian besar pada siswa, Namun setelah diperkenalkan adanya penambahan latiahan model Push Up siswa jadi lebih tertarik dan antusias, Dari hasil pengkajian hasil pada kondisi awal muncullah permasalahan pada pembelajaran Tolak Peluru ini. Kepasifan siswa dalam pembelajaran siklus 1 guru merubah adanya tambahan Push Up, langkah ini ternyata merubah situasi pembelajaran menjadi lebih menarik dan anak semakin berantusias .Pembelajaran yang awalnya biasa mampu menggugah siswa untuk menerima dan anak benar benar ada suasanya menyenangkan .rasa takut dan rendah diri yang ada pada anak sudah diminimalisir karena yang dihadapi teman belajar .Dengan semangat yang semakin terpacu dalam proses pembelajaran ini , baik yang tuntas maupun yang belum berhasil, hasil kondisi pertama 13 siswa meningkat pada siklus kedua 4 siswa dan siklus ke dua menunjukkan peningkatan yang membanggakan yaitu 89,47 \% siswa 
mencapai keberhasilan dalam melakukan Tolak Peluru, Jika penelitian ini dilanjutkan sangat mungkin keberhasilan ini mencapai 100\%dalam mencapai KKM 73 atau lebih maksimal lagi.

\section{PENUTUP}

Dari hasil pembahasan penelitian tindakan kelas ini dapat disimpulkan sebagai berikut:, Kegiatan Pembelajaran pendidikan jasmani dan olahraga cabang Tolak Peluru dapat ditingkatkan dengan model. Peningktan hasil pembelajaran tolak peluru ini karena siswa kelas 7C semester 2 SMP Negeri 1 Kesugihan Kabupaten Cilacap pro aktif, kreatif, inisiatif, dan senang dalam berolah raga atletik dengan penambahan model Push Up agar ada peningkatan kekuatan otot lengannya. Peningkatan pembelajaran lompat jauh melalui model Push Uph dinyatakan berhasil karena ada dukungan yang bervariasi yaitu lompat jauh meliputi: tahap awal, luncuran, , tahap akhir dan tolakan.

\section{DAFTAR PUSTAKA}

Adang Suherman. (2008). Dasar-Dasar Penjaskes. Jakarta: Depdikbud. Direktorat Jendral Pendidikan Dasar dan Menengah

Agus Mahendra. (2004). Azas dan Falsafah Pendidikan Jasmani. Jakarta: Depdiknas.

Direktorat Jendral Pendidikan Dasar dan Menengah Direktorat Tenaga Kependidikan. Bagian Proyek pengendalian dan Peningkatan Mutu Guru Penjas Dikdasmen.

Depdiknas. (2007/2008). Kurikulum Tingkat Satuan Pendididan Standart Kompetensi dan Kompetensi Dasar Pendidikan Jasmani, Olahraga dan Kesehatan, Jakarta: Depdiknas.

Suharno HP. (1993). Metodologi Pelatihan. Yogyakarta: IKIP Yogyakarta.

Suharsimi Arikunto. (1989). Prosedur Penelitian suatu Pendekatan Praktek. Jakarta: PT. Rineka Cipta.

Engkos Kosasih, 1993. Olahraga teknik dan program latihan. Bandung: Akademi Presindo.

M. Sajoto.1998. peningkatan dan pembinaan kondisi fisik dalam olahraga. Semarang: Dahara Price 